\title{
Green Space Based on Oxygen Needs Post-Disaster in Palu City, Central Sulawesi, Indonesia
}

\author{
Abdul Wahid ${ }^{1}$ Annisa Triutari ${ }^{1}$ Budi Setiawan ${ }^{1, *}$ \\ ${ }^{1}$ Forestry Faculty, Tadulako University. Jl. Soekarno Hatta Km. 9, Kampus Bumi Tadulako, Tondo, Mantikulore, Palu \\ 94148, Central Sulawesi, Indonesia \\ *Corresponding author. Email: budi_pascaunmul@yahoo.com
}

\begin{abstract}
The problem of green open space $(\mathrm{RTH})$ in terms of quantity and quality was currently experiencing a significant decline. It impacted the decreasing quality of the living environment of urban residents. It should not have happened because of the existence of Law Number 26 of 2007 concerning Spatial Planning. It states that urban spatial planning must include a plan for the provision and utilization of green open space with a minimum area of $30 \%$ of the total area of the city, the problem of green open space had been proven in studies including $(1,2,4,8,10,11)$. None of the RTH research above had examined the need for green space for oxygen after the earthquake, tsunami, and liquefaction on September 28, 2018, in Palu City. Therefore, this study aims to determine the green open space in Palu City after the disaster based on oxygen to Palu City in 2019. This research was carried out in Palu City, Central Sulawesi. The method used was descriptive analysis and used the Gerakis formula (1974) modified by Wisesa (1988) to calculate the adequacy of green open space based on the oxygen required in Palu City. The results showed that the oxygen demand for the population of Palu in 2019 was 197.43 ha, which was very far from the actual data on the area of green open space in Palu City, which was 1,679.51 ha. Three districts had not met the needs of oxygen, namely West Palu, East Palu, and South Palu Districts, all of which were in the centre of Palu City and experienced a disaster. There was a change in land function from Green Space to settlement and temporary shelter and permanent shelter after the disaster.
\end{abstract}

Keywords: Green open space, oxygen needs, population, disaster, land function changes

\section{INTRODUCTION}

The problem of green open space (RTH) in terms of quantity and quality was currently experiencing a very significant decline. It impacted the decreasing rate of the living environment of urban residents. It should not have happened because of Law Number 26 of 2007 concerning Spatial Planning, which mandates urban spatial planning must contain plans for the provision and utilization of RTH with a minimum area of $30 \%$ of the city's total area. This was experienced in Manado City in fulfilling Manado City RTH needs to be based on providing oxygen, so everyone was required to plant three trees in an area of $25 \mathrm{~m}^{2}$ [1].

The problem of green open space (RTH), according to [2] in the area of Kota Tengah, Gorontalo City that currently was still insufficient compared to the need for green open spaces based on the percentage of area-based on Law No. 26 of 2007 concerning Spatial Planning. It was stated in the law that the proportion of green open space was at least $30 \%$ of the existing area. The ratio of the size of $30 \%$ was the minimum proportion. The site must contain greenery, including both naturally grown and planted crops. But in reality, many available green open spaces (RTH) have been converted into supporting human activities facilities. Green Open Space (RTH) also plays a role in providing oxygen needs for humans, animals, and motorized vehicles. The increasing population, the number of animals, and the number of motorized vehicles will affect oxygen demand. Green Open Space (RTH) was essential to supply consumers' oxygen needs and improve the urban environment's quality.

Similar to the area of Palu City, especially in areas of centers for residential and trade activities, it shows that environmental conditions have not provided optimal comfort, especially when viewed from the aspect of climate comfort, especially temperature, research results were found [1] regarding the Analysis of Broad Relations Green Open Space (RTH) and Changes in 
Temperature in Palu City from 13 years from 1997 to 2010 it was found that open green spaces decreased from $48.86 \%$ to $29.48 \%$.

The results of research conducted by [3] concerning the Analysis of the Need for Green Open Space (RTH) based on the Total Population and Area of Palu City, Central Sulawesi Province, found 2 (two) Districts that do not have sufficient green open space (RTH), namely West Palu District and East Palu District. Therefore, the authors were interested in researching the same location with different parameters with the title of research on Analysis of Green Open Space Needs (RTH) Based on Oxygen Needs in Palu City.

From the background described above, the problem formulation in this study was how the Green Open Space that occurred in Palu City after the disaster was based on oxygen to the population in Palu City in 2019. Based on the formulation of the problem above, the study aimed to determine the Green Open Space in Palu City after the disaster based on oxygen to the number of residents in Palu City in 2019. This research was useful to provide information about the area of Green Open Space (RTH) currently needed based on oxygen demand for the population in Palu City in 2019. This study's results can formulate the direction of urban development policies that were environmentally sound and produce relevant practical recommendations.

\section{RESEARCH MATERIALS AND METHODS}

\subsection{Time and Place}

This research was conducted from January to March 2020, carried out in Palu City, Central Sulawesi Province. Palu City was located between $0^{\circ}, 36$ "- $0^{\circ}, 56^{\prime \prime}$ South Latitude, and $119^{\circ}, 45$ "- $121^{\circ}, 1$ " East Longitude. With an area of 39,506 ha, Palu City has eight subdistricts and 43 urban villages (BPS Palu City).

\subsection{Materials and Tools}

The materials used were the administrative map of Palu City, Palu City green open space data, Palu City population data, Palu City Spatial Plan (RTRW), and laws and regulations related to Green Open Space (RTH). The tools used were a set of computers/laptops, calculators, and digital cameras.

\subsection{Research Implementation Techniques}

This research's implementation was divided into four stages: preparation, data collection, field survey, and data analysis and interpretation.

\subsubsection{Preparation}

Literature studies related to research topics were carried out at this preparation stage, and the supporting data used were books and various journals or scientific articles.

\subsubsection{Data Collection}

The type of data used was secondary data obtained from related agencies required for research. Data collected consists of spatial data, numerical data, and supporting data from field survey results, primary data, namely direct observation to the research location to see the bad RTH situation. based on the results of the analysis that had been carried out, the spatial data of the Palu City Administration Map, numerical data in the form of statistical data including population data, and the area of Green Open Space (RTH) in Palu City [4-7].

\subsubsection{Field Survey}

The field survey included observations of land use in the form of Green Open Space (RTH) in Palu City, selecting sample points to see the inadequate state of green open space based on the results of the analysis that had been carried out so that the causes of the lack of green free space in the area can be identified.

\subsubsection{Data Analysis and Interpretation}

The analytical method used was descriptive analysis to determine green open space (RTH) based on oxygen demand.

\subsection{Analysis of Green Open Space Needs to be Based on Oxygen Needs}

Determine of Green Open Space (RTH) based on oxygen demand was done by analyzing the population according to the amount of oxygen needed per day using the formula Gerakis (1974) modified by Wisesa (1988) in [8-10] as the following equation 1 :

$\mathrm{Lt}=\frac{\text { At (grams/day) }}{54 \times 0,9375}$

Notes: $\mathrm{Lt}=$ area of green open space in 2019, At $=$ The amount of oxygen needed for the population in 2019 
(grams/day), $54=$ Constant value, which indicated that 1 $\mathrm{m}^{2}$ of the vegetated land area produces 54 grams of plant dry weight per day (this constant was the average yield of all types of plants in the form of trees, shrubs/shrubs, shrubs or grasslands (grams dry weight $/ \mathrm{m}^{2}$ ), $0.9375=$ constant value indicated that 1 gram of plant dry weight was equivalent to the production of 0.9375 (grams O2/grams dry weight). The amount of human oxygen demand was $0.864 \mathrm{~g} /$ day (Wisesa, 1988) in [8-10] with the assumptions used in this study that everyone consumes the same amount of oxygen every day.

\section{RESULTS AND DISCUSSION}

\subsection{Description of Green Open Space in Palu City Based on the RTRW of Palu City}

The Regional Spatial Plan (RTRW) for Palu City 2010-2030, provides an overview of Article 40, according to Perda No: 16, which was as follows:

(1) The plan for green open space in Palu City, as referred to in Article 37 letter c, consists of

a. Public green open space; and

b. Private RTH.

(2) Existing public RTH in Palu City as referred to in paragraph (1) letter a covering an area of approximately 1,833 ha or roughly $4.64 \%$ of the total area of Palu City covering:

a. City parks that were distributed in the districts of East Palu, South Palu, and West Palu, with an area of approximately 7.39 ha;

b. The urban forest covers an area of roughly 395.56 ha covering the area of East Palu District;

c. Public Cemeteries and Heroes Cemetery covering an area of about 91.39 ha, which were distributed in North Palu District, East Palu District, South Palu District, and West Palu District;

d. Arboretum in Talise Village, East Palu District, covering an area of \pm 95 ha;

e. The buffer area for Tahura in Poboya Village was \pm 21.64 ha;

f. The forest buffer zone in West Palu District was \pm 208.40 ha;

g. The forest buffer zone in East Palu Subdistrict was \pm 134.41 ha;

h. The forest buffer zone in North Palu District was \pm 327.69 ha; i. The downstream industrial area buffer area in East Palu District covering an area of approximately 112.79 ha;

j. The buffer area for the downstream industrial space in South Palu District covering an area of roughly 135.81 ha;

k. The buffer area for livestock settlement areas in South Palu District was approximately 94.25 ha;

1. The KKOP buffer area around Mutiara Airport, North Birobuli Village, South Palu District, covering an area of 127.17 ha;

m. The green lane along roads in Palu City covering an area of 2.15 ha;

n. Green open fields were located in North Palu District, East Palu District, South Palu District, and West Palu District, covering approximately 79.34 ha.

(3) Private RTH referred to in paragraph (1) letter b included residential yards and office yards.

(4) The plan to develop RTH for Palu City to reach $30.10 \%$ of the city's area was $11,889.74$ ha, which consists of $20.00 \%$ Public RTH and $10.10 \%$ Private RTH included:

a. RT and RW development of parks which will be distributed to the centres of settlement development units;

b. Utilization of front pages of government and private offices as public parks;

c. Development of urban gardens that will be distributed in every sub-district and sub-district in the City of Palu;

d. Development of median and pedestrian roads in Palu City as green open spaces;

e. The development of green open spaces in the Palu Industrial Estate in North Palu District in the form of environmental parks, pedestrian parks, and road medians covering an area of approximately 300 ha;

f. Development of agro-tourism in Lambara Village, North Palu District, covering an area of roughly 150 ha;

g. Development of urban forest in Kawatuna Village, South Palu District, covering an area of approximately 100 ha and botanical gardens in North Palu District covering an area of roughly 200 ha;

h. Development of SUTT border areas in North Palu and East Palu Districts covering an area of about 55.18 ha; 
i. Urban Forest Development in East Palu District covering an area of roughly 612 ha;

j. Development of the KKOP area around Mutiara Palu Airport into a Green Open Space covering an area of approximately $165.3 \mathrm{ha}$;

k. The development of functions of other regions protected into green open spaces, which include coastal boundaries, river boundaries, around springs, High Voltage Airway (SUTT) borders, disaster-prone areas, and geological protection for the city of Palu.

\subsection{Description of Green Open Space in Palu City Based on the RTRW Mapping for Palu City}

The results of the 2010-2030 Palu City Spatial Planning (RTRW) mapping analysis provide a more concrete picture of the green open space (RTH) from 2010. This can be seen in Figure 1.

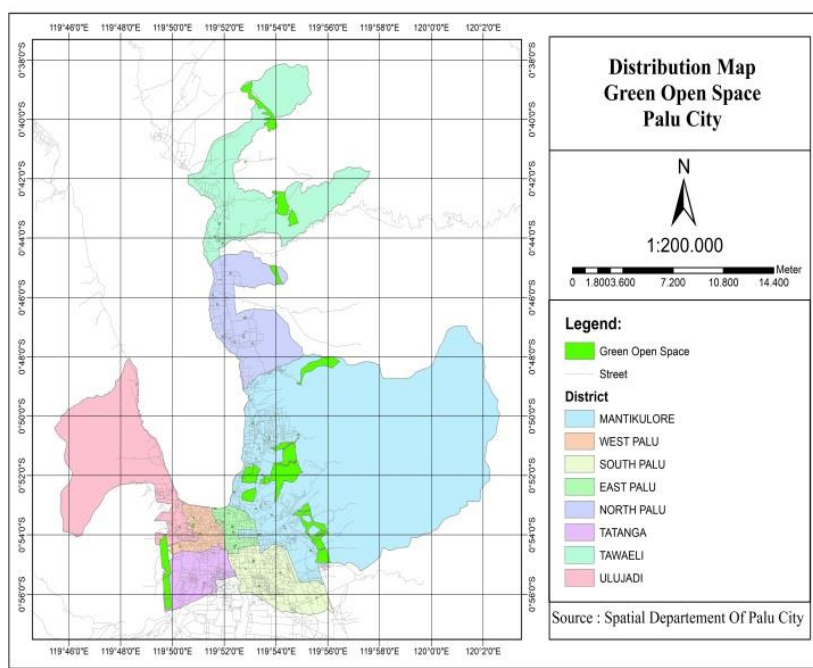

Figure 1 Map of Distribution of Green Open Space (RTH) in Palu City

From Figure 1 above, it can be seen that the distribution of green open space in each district with the area of green open space obtained based on the following shapefiles.

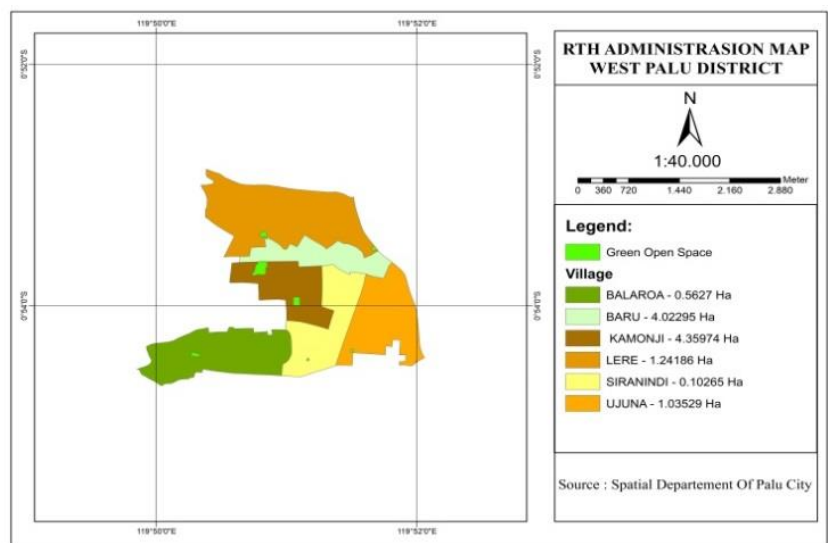

Figure 2 Map of green open space administration in West Palu District

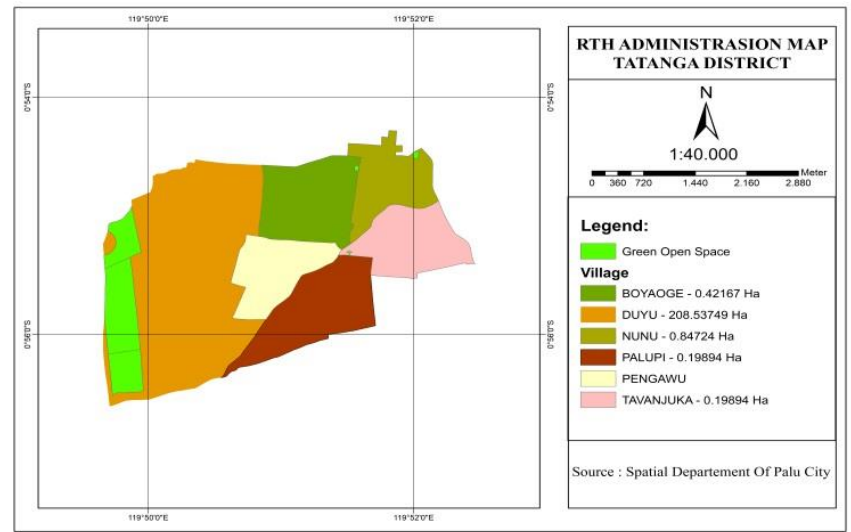

Figure 3 Map of green open space administration in Tatanga District

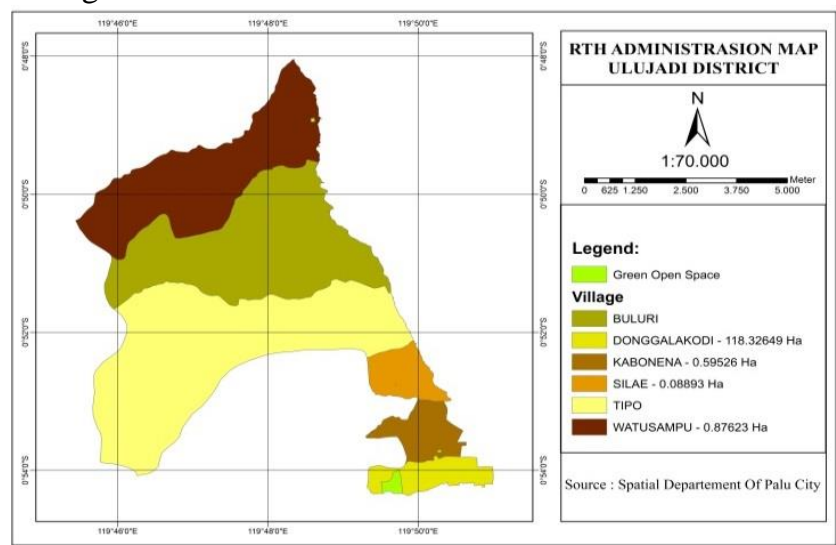

Figure 4 Map of green open space administration in Ulujadi District 


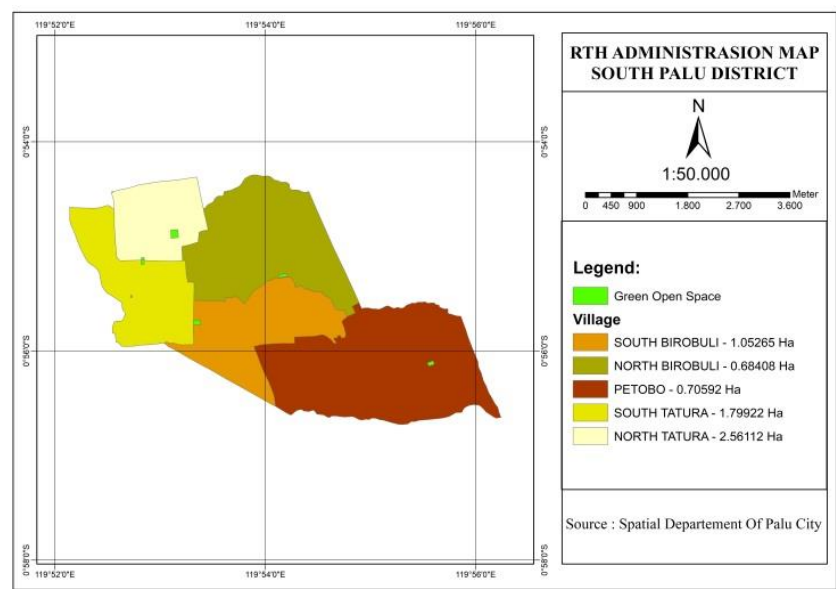

Figure 5 Map of green open space administration in South Palu District

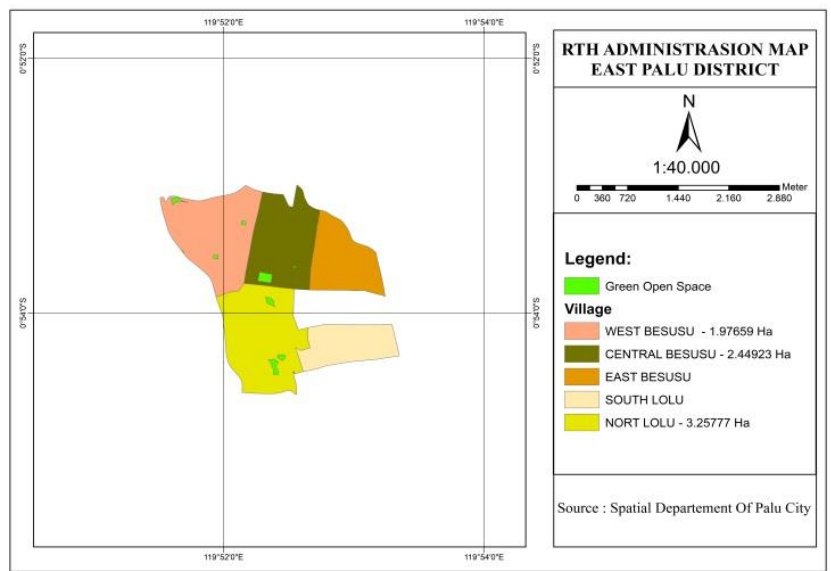

Figure 6 Map of green open space administration in East Palu District

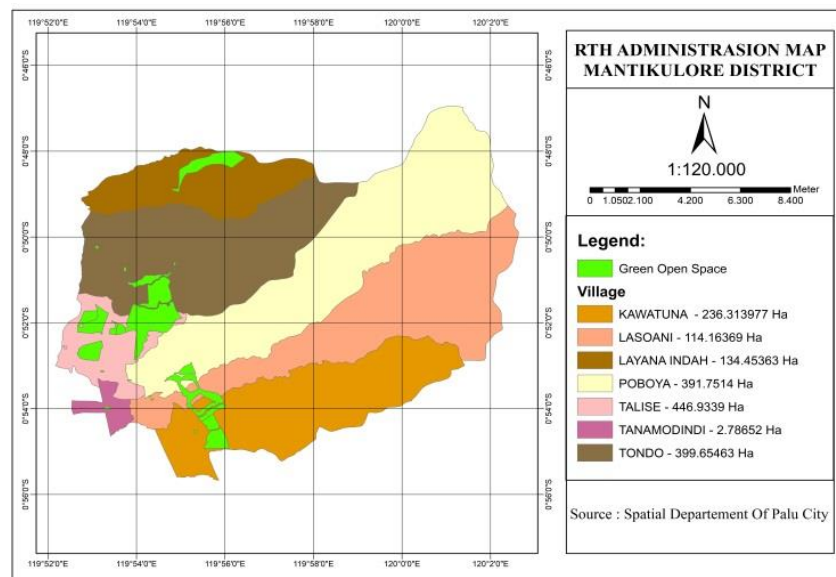

Figure 7 Map of green open space administration in Mantikulore District

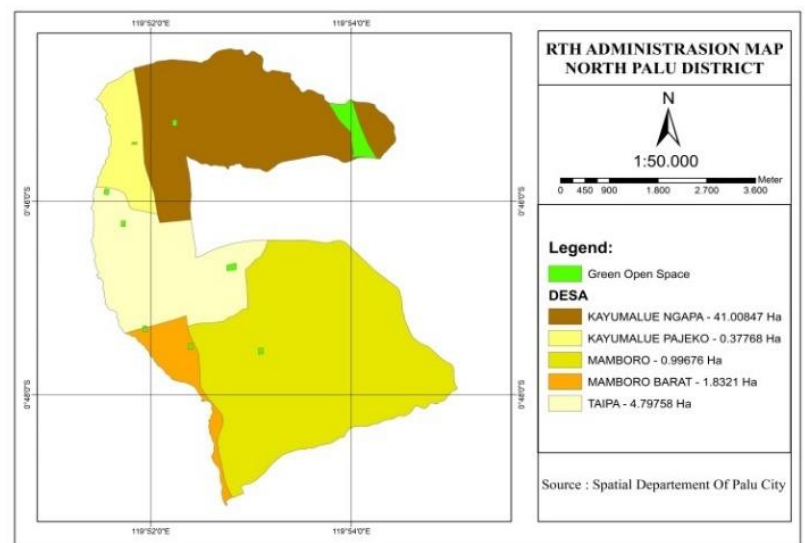

Figure 8 Map of RTH Administration in North Palu District

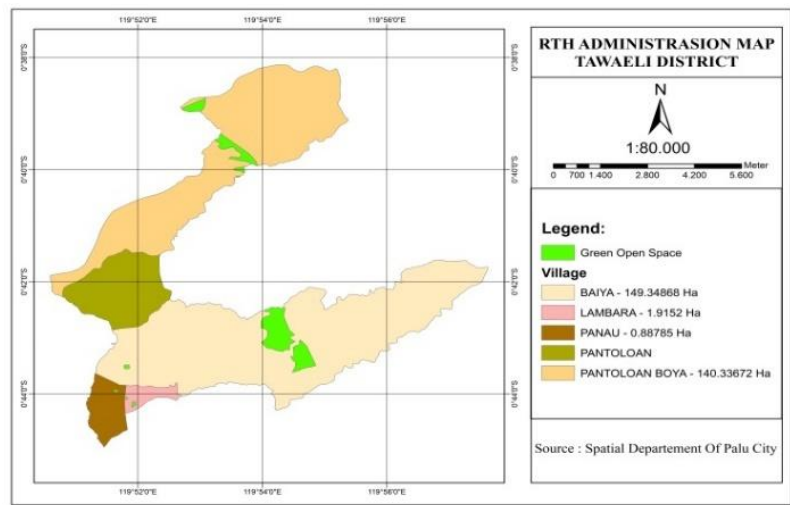

Figure 9 Map of green open space administration in Tawaeli District

\subsection{RTH Needs Based on Oxygen Fulfilments Compared to RTH in RTRW Palu City}

The amount of oxygen demand in Palu City every year had increased along with the increase in population. The people's size will determine the area of the expected Green Open Space (RTH) requirement. The balance of green open space (RTH) based on the RTRW of Palu City, which was detailed for each sub-district, already looks different according to Figure 2 to Figure 9 of the district's availability and needs area. To be more comprehensive, the results of the analysis of the need for Green Open Space (RTH) needed by Palu City in 2019 were based on the number of populations towards oxygen needs, namely as follows: 
Table 1. Suitability analysis of green open space based on oxygen fulfilment with actual green free space in Palu City

\begin{tabular}{|r|l|r|r|r|r|}
\hline No & Sub District & $\begin{array}{c}\text { The number of } \\
\text { residents of Palu city } \\
\text { who have RTH } 2019\end{array}$ & $\begin{array}{r}\text { Population oxygen } \\
\text { demand (g/day) in } \\
2019\end{array}$ & $\begin{array}{c}\text { Area of RTH based } \\
\text { on oxygen needs (ha) }\end{array}$ & $\begin{array}{c}\text { Actual RTH area of } \\
\text { Palu city (ha) }\end{array}$ \\
\hline 1 & Palu Barat & 51,397 & $16,208,557.92$ & 32.02 & 20.62 \\
\hline 2 & Tatanga & 33,103 & $10,439,362.08$ & 13.10 & 210.20 \\
\hline 3 & Ulujadi & 21,036 & $6,633,912.96$ & 44.64 & 119.89 \\
\hline 4 & Palu Selatan & 71,657 & $22,597,761.52$ & 27.84 & 6.90 \\
\hline 5 & Palu Timur & 44,685 & $14,091,861.60$ & 35.19 & 7.68 \\
\hline 6 & Mantikulore & 56,496 & $17,816,578.56$ & 14.67 & 983.36 \\
\hline 7 & Palu Utara & 23,550 & $7,426,728.00$ & 9.35 & 49.01 \\
\hline 8 & Tawaeli & 15,009 & $4,733,238.24$ & 197.43 & 292.49 \\
\hline & Total & 316,933 & $99,948,000.88$ & $1,679.61$ \\
\hline
\end{tabular}

Source: BPS Palu city in 2020 figures and Palu City Spatial Plan 2010-2030

Based on the results of the analysis using the parameter of the total population of the Green Open Space (RTH), it was found that the districts that fulfil the green open space (RTH) were based on oxygen needs, namely West Palu Subdistrict, whose RTH conditions were 32.02 ha. In comparison, the actual RTH was only 10.08 ha. Likewise, in East Palu District, where the need for RTH was 27.84 ha while the actual RTH was only 7.68 ha. While South Palu District, whose green open space needs based on the needs of oxygen was quite large, 44.64 ha when compared to the actual RTH 6.80 ha, which means that there was Green Open Space that had been converted to land as in Figure 10 below, which was one of the causes of the mismatch of broad needs. 

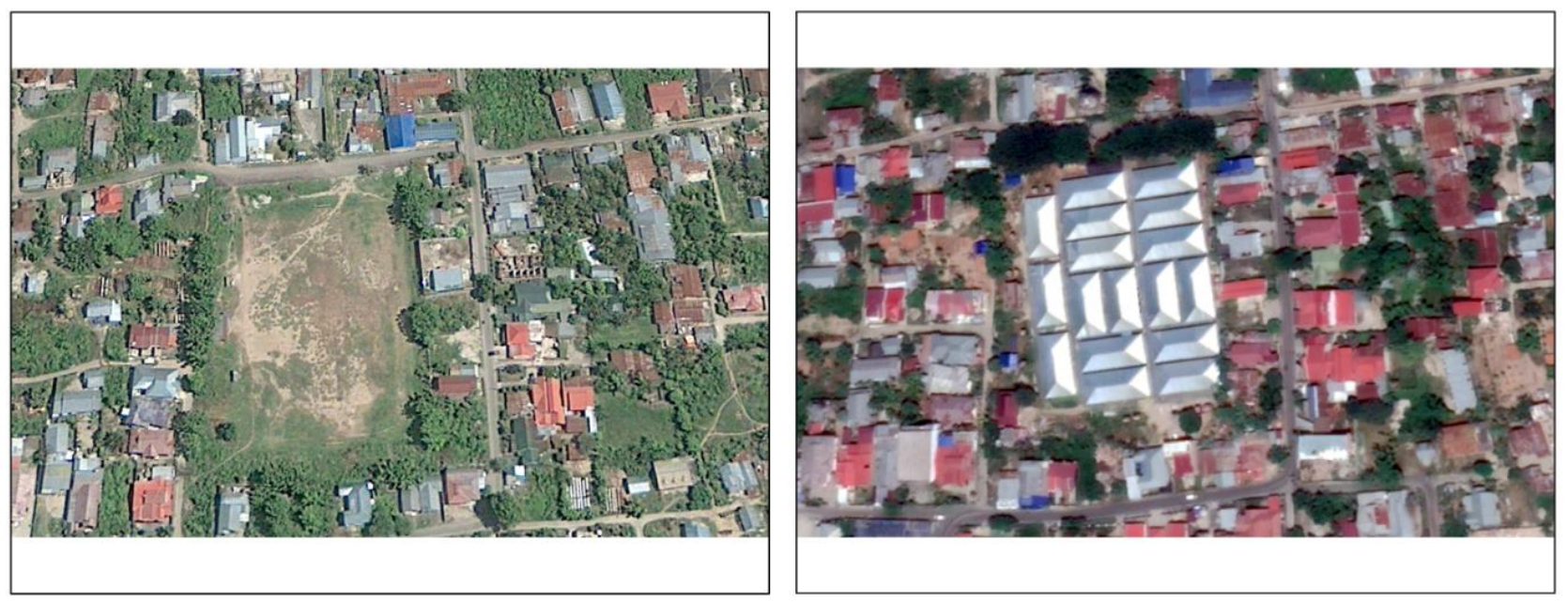

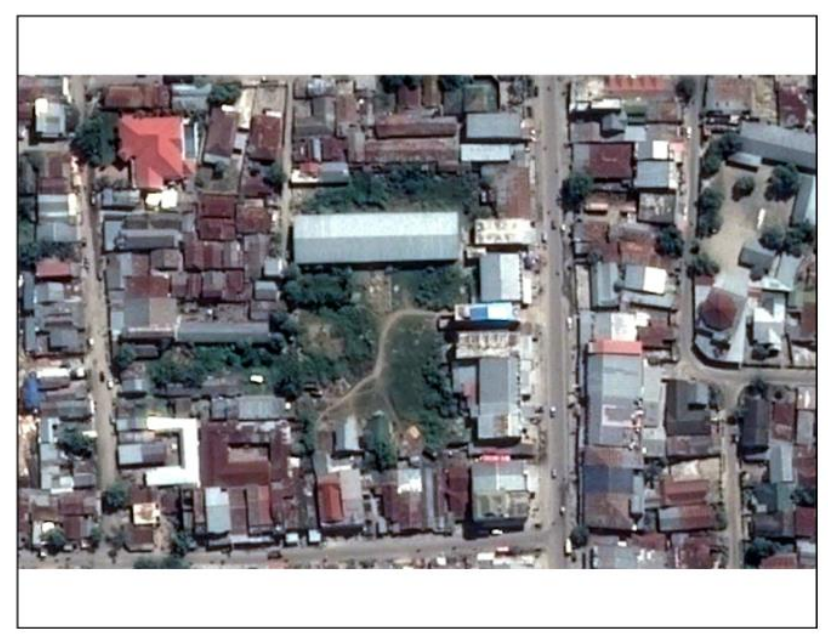

2010

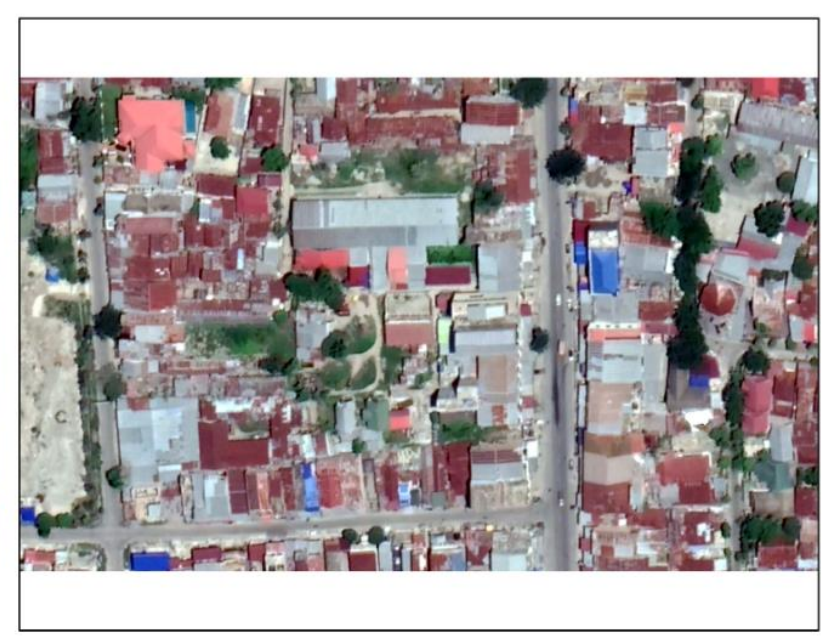

2020

Figure 10 Green Open Space that had been converted to land from 2010 and 2020

\section{CONCLUSION}

The conclusion that can be drawn from the results of this study was that the Green Open Space (RTH) needed in Palu City based on Oxygen needs for the population in 2019 was 197.43 ha, which was very far from the actual data on the area of Green Open Space in Palu City, which was 1,679.51 Ha. However, there were still 3 Districts that have not met their oxygen needs, namely West Palu, East Palu, and South Palu Subdistricts, all of which were in the center of Palu City, and it was evident that there had been a change in land function from Green Open Space to settlement.

\section{REFERENCES}

[1] F. Rahman, J. I. Kalangi, F. B. Saroinsong, Analysis of Manado city green open space needs based on oxygen providers' function, Cocos, 2018.

[2] S.S. Arifin, Analysis of the need for green open space in Kota Tengah sub-district, Gorontalo city. RADIAL: Journal of Civilization Science, Engineering and Technology, 2, 2014, pp. 27-31.

[3] F. Ahmad, H. S. Arifin, E. N. Dahlan, S. Effendy, R. Kurniawan, Analysis of the relationship between green open space (RTH) and temperature changes in Palu City. Journal of Tropical Forests, 13, 2016.

[4] Central Statistics Agency for Palu City, Palu city in figures in 2020, BPS Palu City, Palu, 2020. 
[5] Directorate General of Spatial Planning, Ministry of Public Works, Regulation of the Minister of Public Works No: 05/PRT/M/2008 concerning guidelines for the provision and utilization of green open space in urban areas, Public Works Department, Jakarta, 2008.

[6] Spatial Planning Service Palu City, Palu City in numbers 2018, TTR Palu City, Palu, 2018.

[7] Regional Spatial Planning Palu City 2010-2030, 2019. http://perpustakaan.bappenas.go.id/lontar/ file?file=digital/131177-[_Konten_]-Konten\%20C9 264.pdf

[8] R. Lestari, I. Jaya, Using satellite and GIS remote sensing technology to determine urban forest areas: (case study in Bogor City, West Java), Journal of Tropical Forest Management, 11, 2005, pp. 55-69.

[9] W. Setyani, S. R. P. Sitorus, D. R. Panuju, Analysis of green open space and its adequacy in the city of Depok, Soils and Lands Bulletin, 1, 2017, pp. 121127.

[10] F. M. Shani, A. Kurniawan, Study the availability and need for green open space in urban areas in Sukabumi city. Bumi Indonesia Journal, 4, 2015. 